\title{
Black Hawk and the Historians: A Review Essay
}

\author{
ROGER L. NiCHOLS
}

Wilderness Journey: The Life of William Clark, by William E. Foley. Columbia: University of Missouri Press, 2004. 326 pp. Illustration, notes, bibliography, index. $\$ 24.95$ paperback and e-book.

William Clark and the Shaping of the West, by Landon Y. Jones. New York: Hill and Wang, 2004. 394 pp. Illustrations, maps, notes, bibliography, index. \$19.95 paperback.

William Clark: Indian Diplomat, by Jay H. Buckley. Norman: University of Oklahoma Press, 2008. 306 pp. Illustrations, maps, notes, bibliography, index. \$29.95 hardcover, $\$ 19.95$ paperback.

Mr. Jefferson's Hammer: William Henry Harrison and the Origins of American Indian Policy, by Robert M. Owens. Norman: University of Oklahoma Press, 2007. 311 pp. Illustrations, map, notes, bibliography, index. $\$ 19.95$ paperback.

Black Hawk and the Battle for the Heart of America, by Kerry A. Trask. New York: Henry Holt and Company, 2006. Maps, notes, bibliography, index. $\$ 21.99$ paperback.

Black Hawk and the War of 1832: Removal in the North, by John P. Bowes. New York: Chelsea House, 2007. 131 pp. Illustrations, map, chronology, notes, bibliography, index. $\$ 35.00$ hardback.

The Black Hawk War of 1832, by Patrick J. Jung. Norman: University of Oklahoma Press, 2007. 275 pp. Illustrations, maps, appendix, notes, bibliography, index. $\$ 19.95$ paperback.

Uncommon Defense: Indian Allies in the Black Hawk War, by John W. Hall. Cambridge: Harvard University Press, 2009. Maps, notes, index. \$35.00 hardcover.

IN APRIL 1832 some 1,500-1,800 Sauk and Meskwaki Indians belonging to the so-called British Band crossed the Mississippi River from Iowa into Illinois. As they moved east and north up the Rock River, their "invasion" sent waves of panic through the frontier settlements in northern Illinois, triggering the Black Hawk

THE ANNALS OF IOWA 75 (Winter 2016). (C) State Historical Society of Iowa, 2016. 
War of that summer. At first glance this mostly local war seems to have been only a minor incident in the process of American frontier settlement. However, when looked at in the context of nineteenth-century Indian wars, it had an important part in clearing native people from the upper Mississippi River valley. During that conflict about 70 whites and nearly 1,000 Indians died. About 2,500 frontiersmen served in the militia, joining the nearly 1,000 U.S. regular troops sent to defeat the Indians. Together, the force of soldiers and militiamen numbered about five times the size of George Armstrong Custer's Seventh Cavalry that fought at the Battle of the Little Bighorn two generations later.

Few twenty-first-century readers are likely to know much about this long-past chapter in midwestern history, yet it has captured the imagination of historians ever since it took place. From 1833, when Black Hawk dictated his autobiography to a local journalist, until 1992, when my brief study of his life was published, at least eight authors published books, and others added articles or reminiscences about war. Together, they examine the conflict from all sides, while describing, criticizing, or praising the army, the militia, the Indians, and the government. ${ }^{1}$

1. For much of the nineteenth century, accounts of the war came from participants or those who interviewed them. They begin chronologically with Black Hawk's account in John B. Patterson, ed., Life of Ma-Ka-Tia-Me-She-Kia-Kiak or Black Hawk (Cincinnati, 1833). The next year John A. Wakefield, History of the War Between the United States and the Sac and Fox Nations of Indians (Jacksonville, IL, 1834), gave a militiaman's view of the war. Benjamin Drake, The Life and Adventures of Black Hawk (Cincinnati, 1838), was based on interviews with men who knew Black Hawk or had some role in the events. Ninian Wirt Edwards, History of Illinois from 1778 to 1833; and Life and Times of Ninian Edwards (Springfield, IL, 1870), gives his father's role as governor during the 1820s. John Reynolds, governor during the conflict, gave an anti-Indian account in Reynolds' History of Illinois, My Own Times: Embracing also the History of My Life (Chicago, 1879). Cyrenus Cole, I Am a Man: The Indian Black Hawk (Iowa City, 1938), has the first even-handed history of the war. William T. Hagan, The Sac and Fox Indians (Norman, OK, 1958), put those events in the context of American territorial expansion. The most careful analysis appears in Anthony F. C. Wallace, "Prelude to Disaster: The Course of Indian-White Relations Which Led to the Black Hawk War of 1832," in The Black Hawk War, 1831-1832, ed. Ellen M. Whitney, 2 vols. (Springfield, IL, 1970-1978), 1:1-51. Cecil Eby, "That Disgraceful Affair": The Black Hawk War (New York, 1973), uses a Vietnam-era antiwar slant. Roger L. Nichols, Black Hawk and the Warrior's Path (Arlington Heights, IL, 1992), was the first modern biography before the works discussed in this essay. 
So much has been written about the Black Hawk War that one might think more ink was spilled over it than blood was shed in the real event. And since the beginning of the twenty-first century, scholars have continued to find the events on a midwestern frontier important in regional and national history. Eight recent books tell at least part of the story.

The renewed interest began as an offshoot of the activities marking the bicentennial of the Lewis and Clark Expedition (1804-1806) and at first focused on William Clark's life. After the famous expedition ended, Clark held federal offices in Missouri, and from 1822 until his death in 1838 he served as Superintendent of Indian Affairs there. In that position he oversaw relations with the Sauk and Meskwaki people before, during, and after the Black Hawk War. Although Clark's biographers do not focus on it, that conflict was among the most serious frontier challenges he faced as a federal official, so three recent biographies of Clark deserve some attention here.

The first, Wilderness Journey by William Foley, represents years of research in Missouri history. Foley devotes nearly half of his biography to the famous expedition Clark undertook with Meriwether Lewis. Indian affairs get only some modest attention in parts of the last two chapters, where Foley discusses treaty negotiations, the hosting of tribal delegations at Clark's St. Louis home, and his role in supervising aspects of the fur trade. Within that context Foley shows how Clark had a central role in American dispossession of the Mississippi valley tribes. He and Lewis Cass of Michigan Territory negotiated land cessions and intertribal agreements as they tried to force the tribal people to act as Americans thought they should. Foley briefly questions Clark's competence in dealing with events leading to the Black Hawk War but says little about his lack of effort to prevent or help prosecute it.

In William Clark and the Shaping of the West, Landon Jones gives a more balanced narrative with closer attention to Indian affairs, although his ideas differ only a little from Foley's. His interestingly written narrative traces Clark's acts as a frontier soldier, Missouri political leader, and frontier federal administrator. 
In the last two chapters, he shows that by the 1830s Clark's failing health and family disasters led him to depend on subordinates for much of his dealings with the Indians. As the federal removal policy pushed increasing numbers of Indians west of the Mississippi, those newcomers suffered from shortages of food, clothing, and shelter while being robbed and beaten by lawless frontiersmen. Jones shows that Clark and other federal officials lacked the authority to help the tribes much or to protect them from the pioneers. He demonstrates that Clark had little understanding of Black Hawk's motivations, assuming that the war leader looked to British traders to cause trouble in Illinois.

The third study of Clark shows less interest in the 1804 expedition and more in historians' increasing focus on Indian affairs in the new century. Jay Buckley devotes about half of his book, William Clark: Indian Diplomat, to Clark's dealings with the Indians. Buckley shows how Clark's paternalistic approach to his tribal charges failed to protect the Indians and in the long run helped the United States push them west. In Buckley's view, Clark, although generally competent as an administrator, failed to recognize the pioneers' increasingly aggressive and racist views of Indians. As a leading negotiator of regional treaties, he angered Black Hawk and other tribal leaders and helped shape the events leading to the 1832 war. Working to enforce earlier treaties, Clark ordered his subordinates to urge the Sauk and Meskwaki to move west of the Mississippi in 1829 when the federal government opened their Rock River lands in western Illinois for sale. When the combined efforts of frontier officials failed to persuade Black Hawk and his followers to stay in Iowa, the natives' recrossing of the Mississippi brought war. Buckley's treatment of Clark is more sympathetic than he deserves but does show how federal policies and their implementation created the situation leading to war.

These biographies of William Clark give a broad background of U.S. Indian policies during the early nineteenth century. As interest in celebrating the Lewis and Clark Expedition faded, historians shifted their focus. Between 2006 and 2009 five new books discussing aspects of the Black Hawk War appeared. The first, 
Mr. Jefferson's Hammer, by Robert Owens, analyzes William Henry Harrison's efforts to negotiate treaties with many tribes in the Old Northwest before the War of 1812. As governor of Indiana Territory, he served as the president's front man in getting midwestern tribes to surrender their homelands. Owens spells out clearly how the governor dealt dishonestly with a small Sauk-Meskwaki delegation in 1804, when he persuaded them to sign a treaty ceding their Illinois lands to the United States. Because the tribal negotiators lacked authority to sign any agreement with the government, Sauk leaders rejected the agreement's validity. At the same time, American officials, including William Clark, expected the tribe to follow the treaty. Shortly after the 1804 signing, disputes over the treaty brought sharp divisions among Sauk leaders and between the Indians and American frontier officials, leading directly to the events that caused the war. Owens's study clearly places the Black Hawk War directly in the center of historians' understandings of early nineteenth-century Indian affairs.

In 2006 the first of four books focusing directly on the Black Hawk War appeared. In Black Hawk and the Battle for the Heart of America, Kerry Trask builds on existing ideas about Indian-white relations as he narrates the conflict. His central thesis is that the war resulted from a "tragically redundant pattern" (7) of whiteIndian violence that recurred on nearly all of America's frontiers during the nineteenth century. He sees this as resulting from rapid social changes in American life and ideas as pioneers flooded the region between the Appalachians and the Mississippi River. During that era earlier controls on personal actions disintegrated, frontier settlers seized Indian lands, and violence and hatred grew sharply. According to Trask, these factors created situations leading directly to war.

In the first half of the book, he presents a thoughtful and carefully documented account of Sauk and Meskwaki life in the region, with emphasis on their ideas, social practices, and self-identity. That allows him to show how tribal customs shaped how the villagers dealt with other Indians but did not work effectively when facing white pioneers or their government. In fact, the analysis 
emphasizes how white demands and expectations ignored or rejected tribal ideas. For example, under the 1825 treaty of Prairie $\mathrm{du}$ Chien, the Indians of the upper Mississippi valley agreed to stop raiding each other, to stay out of each other's hunting territories, and to depend on federal officers to settle intertribal disputes. This latter provision rejected the basic Indian custom of clan revenge against outsiders who harmed the villagers or their property, and tribal leaders had no authority to enforce it on their people. The narrative clarifies how that brought a cycle of violence rather than ending it, keeping the area in turmoil for years.

Trask provides a clear narrative of the war itself. He traces the motivations and movements of Black Hawk's followers, the British Band, from their entry into Illinois in April 1832 to the crushing defeat and slaughter at the Battle of Bad Axe four months later. Trask clearly presents the varied roles of Neapope, the Winnebago Prophet, and bands of nearby Indians in the negotiations, raiding, and conduct of the war. He gives General Henry Atkinson credit for having a solid grasp of the situation, but chides him for two mistakes: his inflammatory letters to Governor John Reynolds, and the failure to keep Major Isaiah Stillman's command with his own, which would have prevented the unexpected fight with the Sauk and might have allowed negotiations rather than war. The narrative presents these events clearly and readably, employing Trask's central theme that, given ideas at the time, much of the violence was unavoidable.

Just a year after Trask's book came out, John P. Bowes's Black Hawk and the War of 1832 appeared. It makes no pretense of being an academic study. Rather, it is designed for use by students and aimed at the general reading public instead of scholars. It offers a brief, clear narrative, excellent maps, quotes from contemporary people, and plenty of illustrations. At the same time, the author has done his research carefully, so the narrative rests on a solid scholarly base of published primary items and recent studies of related issues. Bowes locates the 1832 war in the context of the evolving American policy during the era after national independence. 


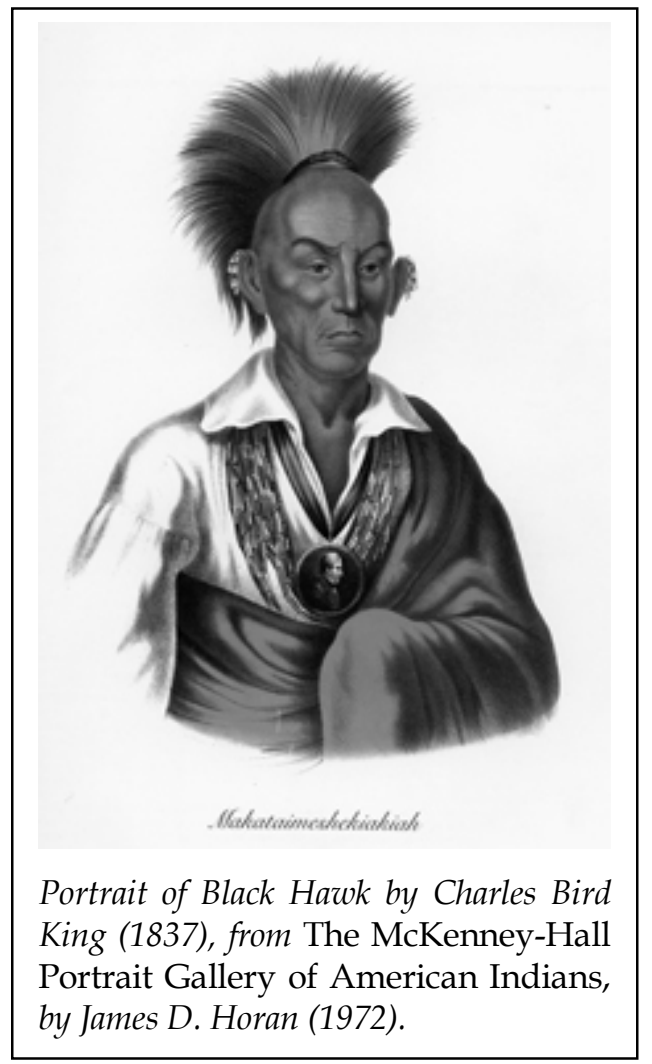

He writes that the new federal government and its citizens came to agree that dealing with the Indians included three basic ideas: the need to keep peace, the recognition that land ownership and use was a central area of dispute, and the assumption that Anglo-Americans and their government knew what was best for the tribal people. Using thumbnail sketches, Bowes shows how expanding frontier settlement brought ever more pressure on the government to manage Indian relations peacefully while opening ever more land for the pioneers. By 1830 this resulted in what became known as Andrew Jackson's Indian Removal Policy, and that, in turn, focused attention on tribes in the upper Mississippi valley. Under the terms of a questionable treaty signed in 1804, the Sauk and Meskwaki people in northern Illinois had to move west. When a portion of those tribes returned to Illinois in 
1832, their actions led to the Black Hawk War. While this book adds little to the story, its analysis is clear and the scholarship is up to date. The result is an attractive, brief, and readable account of the conflict.

In The Black Hawk War of 1832, Patrick Jung takes a distinctly different approach. He offers a detailed scholarly analysis of the conflict. His narrative connects with several others discussed above, showing how federal negotiators worked to clear the native villagers out of areas the encroaching whites wanted. As with most of the other accounts, he shows how William Henry Harrison's 1804 treaty took Sauk and Meskwaki land east of the Mississippi without the tribal negotiators realizing what had happened, at least for a time. He traces the growing divisions within the tribal leadership and the more than decade-long competition between Black Hawk and Keokuk for influence within the Sauk villages. Related to those tensions within the tribes, the narrative also depicts how ongoing rivalries and disputes with the nearby Sioux, Ho-Chunk [Winnebago], and Menominee kept tensions in the region near the surface.

Recognizing that this war has been studied frequently, Jung shifts the focus from a straight narrative of the events to emphasizing the roles of the neighboring tribes in the conflict. He discusses tensions between the encroaching lead miners in the Dubuque's Mines area in Iowa, as well as near Galena, Illinois, and in southwestern Wisconsin. Then he traces the continuing intertribal violence based on clan revenge customs for settling intertribal disputes. The book offers a clear view of difficulties facing American frontier commanders when they had to integrate untrained pioneer militiamen into forces of army regulars. Jung presents the conflicting goals and actions of frontier politicians, the desires of the local white inhabitants, and the actions of federal officials dealing with Indian affairs.

He is particularly effective in describing and analyzing the military actions during the war. He uses the existing multitribal competition and conflicts as part of the background and of the war, too. His narrative demonstrates the variety of tribal re- 
sponses. At least one band of Kickapoo joined Black Hawk's followers. While some Ho-Chunk [Winnebago] remained neutral, others fought for or against the Sauk. The Potawatomi used the war to settle old grudges against individual pioneers, but both the Sioux and the Menominee sought revenge against the Sauk for earlier raids. The narrative traces troop movements throughout the summer of 1832, comments on General Atkinson's effectiveness, and describes the decimation of most of the 1,500 or more Indians caught in the disaster. For the Indians, things became even worse when the fighting ended. At that point, the United States demanded that they surrender their claims to much of eastern Iowa, setting the stage for their forced removal from the state.

John Hall's Uncommon Defense is the most recent study of the war. While it traces many of the same developments leading to the strife as do the other books reviewed here, Hall's study moves beyond them. He broadens the focus, shifting the emphasis from an Indian-white conflict to one that included Indian-onIndian violence. Clearly aware that during the generations of interracial fighting, natives fought alongside whites against their tribal enemies in virtually every "Indian war," Hall shapes his discussion accordingly. The book's central contribution to a full understanding of the Black Hawk War, then, is its emphasis on the varied and shifting roles of the neighboring tribes as they tried to use the fighting to attain their own objectives. Hall's thesis is that the violence resulted when two separate conflictswhite-Indian and Indian-Indian - came together.

He examines the long-term rivalries that resulted from generations of tribal migrations, fur trade competition, and shifting Indian-European alliances in the upper Mississippi valley. Gradually, those rivalries created a situation in which well-armed young hunters of the competing groups raided each other for several generations. That violence helped young men to achieve warrior status while meeting their clan obligations to seek revenge for violence against their relatives. Once American pioneers began filtering into the region after the War of 1812, federal officials worked to end the raiding, but that only increased Indian distrust of and 
anger toward the newcomers. Despite a series of treaties in 1816, 1825 , and 1830, intertribal competition and conflicts continued.

Hall's analysis demonstrates how leadership quarrels among the Sauk and Meskwaki led to the development of the British Band, which followed Black Hawk. Then he examines the relations between that group and the nearby Ho-Chunk [Winnebago], Dakota Sioux, Menominee, and Potawatomi. The HoChunk had complicated relations with the British Band as differing bands fought on their side, aided the whites, or stayed neutral. The Sioux and Menominee joined the whites, fighting against Black Hawk's followers to avenge past raids. The Potawatomi used the confused situation to attack some intruding pioneers, and then tried to remain neutral. This narrative explains clearly what motivated each of the tribes and shows how the acts of some Métis leaders shaped events, too. Hall suggests that while the tribes used the war to gain their own short-term goals, their actions weakened any chance they had to resist forced removal beyond the Mississippi.

Placing the Black Hawk War into a shifting and complex context, Hall uses knowledge of the tribal communities and their goals effectively. His focus on Indian motivations and diplomatic maneuvers offers a model that can help better understand many of the nineteenth-century Indian wars, because native allies took part in virtually every Indian war. Hall's book combines the latest scholarship with fine writing and excellent maps. Coming at the end of nearly a decade of research related to the Black Hawk War, the analysis combines the best elements of recent scholarship. It seems to me highly unlikely that much more is needed on the topic for at least a generation, or until historians begin to ask new questions about the past. 